\title{
Herbert: A Short History of Reading ${ }^{1}$
}

\begin{abstract}
This paper sets out to address issues relating to the reception of Zbigniew Herbert's poetry and essays, and the scope here is bookended by his debut collection of poetry at one end and most recent commentaries and reviews by researchers and critics on the other. This overview of the scholarship which has come to be referred to as "Herbertian studies" extends its coverage to changing styles of reading, issues pertaining to aesthetics and beliefs, axiological dimensions, applied research methodologies, and interpretative angles. This outline of the history of the perception of Herbert's legacy is organised chronologically, thematically and notionally. The analysis in hand focuses on key monographic papers, comprehensive studies, and reviews illustrating the order of the multiplicity of approaches and dimensions of analysis; furthermore, it sheds light on the variety of styles and methods of reading and chronicles the extended tradition of attempts at examining such works' content and messages. The sheer number of such publications testifies to the popularity of Herbert's output in this respect. The analysis of particular poems serves here as the point of departure for observations of a more general nature: existential and metaphysical interpretations are placed side by side with culturally referenced readings. Still, the catalogue of critical works on Herbert does not seem to be a definitive collection, as, for one, there is no sign of the pool of new interpretations drying up, and moreover, the search for "yet another Herbert" is given impetus by new concepts emerging in the expanding nomenclature in the field of the humanities.
\end{abstract}

Keywords: Herbert's artistic legacy, reception, history of Polish literary criticism, interpretation, methodology, new literary theory

${ }^{1}$ Originally published in Konteksty Kultury 2018, vol. 15, no. 1 (the Polish title: "Herbert: krótka historia czytania"). 


\section{Varied images of the poet and his poetry}

The number of critical studies dedicated to Herbert's literary output has been proliferating so dynamically that, in consequence, even authorities in the field of literary theory cannot help being overwhelmed by the growing bibliography of this fascinating, if intellectually and artistically challenging, subject. ${ }^{2}$ Significantly outgrowing its original paradigm, the study of Herbert's legacy has come of age and morphed into a specialised analytical domain in its own right, meriting the designation of "Herbertian studies." Such multiplying comments regarding this exquisite poet, essayist, playwright, and epistolary writer concern ever more detailed matters. Herbert's writings are being increasingly critically overlaid with novel commentary due to mutating research trends and humanistic interests of subsequent generations of scholars, which stands to reason given the multiplicity of meanings underlying his output and prompting new interpretations.

This consummately intriguing phenomenon of the popularity of Zbigniew Herbert's writings merits thorough analysis. Even putting nuances aside, we can compile a long list of his far-reaching contributions. Firstly, the poet furthered our understanding of ancient civilisations and cultures and elaborated literary reflection on art from the Lascaux Cave paintings through early Renaissance Italian painting, to his favourite $17^{\text {th }}$-century Dutch artists. Secondly, he revived the travelogue genre, speculated on the mechanisms informing the course of history, and opened up new horizons in pursuing philosophical poetry. Thirdly, he blazed a trail in a brand of literature espousing compassion and loyalty, becoming the champion for "the upright position" in times of totalitarian oppression. Fourthly, the perspicacity of his powers of observation allowed him to aptly diagnose the crisis of humanity, and he subjected the nature of existence to poetic perusal. Fifthly, refraining from any declarations of a religious nature, Herbert demonstrated how transcendence bears on human lives, and he also employed elegiac narrative. Sixthly, he opined in a profound way on suffering, dying, and death per se. All matters bound up with the human collective destiny were given by him relevant evaluation against the benchmarks of universal values. Last but not least, he should also be credited with the redefinition of the Romantic paradigm of the charismatic hero, since, as noted

2 This work refers back to an earlier paper, expanded and supplemented with the latest publications regarding Herbert's artistic output: W. Ligęza, "Nieustanne komentowanie. Wokół recepcji Zbigniewa Herberta w Polsce" [in:] Herbert Środkowoeuropejczyk. Twórczość Zbigniewa Herberta w kontekstach i kontaktach środkowoeuropejskich, ed. K. Krasuski, Katowice 2011, pp. 100-149. Issues relating to perception of works are also addressed in the following collective work: Herbert na jezzykach. Wspótczesna recepcja twórczości Zbigniewa Herberta w Polsce i na świecie, ed. A. Grabowski, J. Kopciński, J. Snopek, Warszawa 2010. See also: S. Barańczak, "Nieporozumienia" [in:] idem, Uciekinier z Utopii. Opoezji Zbigniewa Herberta, London 1984, pp. 5-29. 
by Barbara Toruńczyk, "What functioned as apparently Romanticism-derived Polish patriotism, steeped in traditional and Catholic values, he wanted to invest with classical virtues, aligning it with European civilisation."3

Questions concerning Herbert's poetry, dramaturgy, and essays must not be addressed in disjunction from perennially changing sensibilities informing judgements voiced by literary scholars, critics, and aficionados of verse; what also needs reckoning with are fluctuations in aesthetic preferences, philosophical stances, and systems of values. Hence, comments regarding the above realms seem to necessitate a solid footing in experience - both in the case of the writer and from the perspective of his readership. As some reading agendas, sooner or later, seem to run their course or wear out, or undergo metrification, the perception of the same reading matter, taking place in the context of new developments changing in time, will lead to the discernment of aspects previously overlooked. Aleksander Fiut introduces his study with the memorable sentence: "The rotation of the ways in which literary critics portray Zygmunt Herbert is matched by the mobility of the revolving stage." ${ }^{4}$ No wonder that, every now and then, we witness the search for "yet another Herbert," which habitually happens in the wake of historical, social, and cultural developments impinging on the overall profiles of criticism pursued by representatives of subsequent generations.

Beyond the shadow of a doubt, the sentiments surrounding the literary output of the author of Elegy for the Departure varied in sync with the changing circumstances of life. Thus, in communist Poland, when his compatriots found themselves marooned in that coarse and crude reality, they treated literature as a conduit for the vicarious consummation of the Mediterranean dream. Obviously, in the subsequent era of the grassroots Solidarity-driven revival and the retaliatory state-imposed martial law, his poems were viewed as a catechismal compendium of tenets regulating individual and communal life. Yet another transformation in the perception of his works materialised when Poland regained its freedom and witnessed the emergence of a cultural paradigm shift. Finally, even if for a short time and barring his essay output, it was possible to disengage Herbert's poems from the clutches of political interpretation, which allowed for the discernment of themes reflecting his taking stock of personal life and painful predicament.

Over the span of the last six decades, both readers and critics have chosen to construe the contemporaneously popularised Herbert's production in keeping with the urgent needs of the moment; naturally, thus, particular prevailing reading angles were, sooner or later, doomed to predominantly historical significance. A case in point was the casting of Herbert as the exemplary

3 B. Toruńczyk, "Dukt pisma, dukt pamięci," Zeszyty Literackie 1999, no. 4, p. 178, reprinted [in:] Poznawanie Herberta 2, ed. A. Franaszek, Kraków 2000, pp. 74-81.

${ }^{4}$ A. Fiut, "Język wiary i niewiary” [in:] idem, Pytanie o tożsamość, Kraków 1995, p. 141. 
standard bearer for moral revolution, but, despite the resultant downplaying of elements of irony and detachment, the ignored dimensions finally reclaimed acknowledgement. ${ }^{5}$ Arguably, the politicised, patriotic, and freedom-fighting take on Herbert, with such a vantage point being prompted by the need for straightforward and incontrovertible truths, was dismissive of elements of contradiction and irony, which was, to a large extent, in evidence in Polish society's assimilation of "The Envoy of Mr Cogito." ${ }^{6}$ However, following the year 1989, the Aesopian language decrypting approach lost its appeal. Some shifts in reading preferences ensued, and Herbert's mantle of the anti-communist prophet was superseded by the image of an existential and metaphysical poet, a mystagogue revealing arcane truths of existence, an individual sensitive to human misery, someone both believing in the eventuality of coming face-to-face with the divine and exploring the afflictions attendant to man's destiny. His last collection of poems, Epilogue to a Storm, solidifies Herbert's reputation as an artist having a way with words and rising to the challenge of attacking the ars-moriendi matters; in addition, emerging from the volume is a sensibility comprising of both elegiac lamentation and resilient fortitude.

Purely of necessity, this survey generally confines itself to the reception of Herbert's poetic output, albeit it features forays into the public's interest in the realm of essay-writing; occasionally, in passing, allusions will also be made to Herbert's footprint in society in terms of dramatic works and letters. Of course, there is no gainsaying that Herbertian studies have profoundly benefited from, and been advanced by, insights deriving from his prose - essays, literary works and literary criticism publications ${ }^{7}$ - and the same could be said for his miscellaneous works, his translations, and press-published interviews with the writer. The two publishers we have been most indebted to for incessantly bringing Herbert's works to the public's notice are the Zeszyty Literackie Publishing House and the Wydawnictwo a5 Press.

5 M. Zaleski notes that "recognition was achieved through vilification of [Herbert's - W.L.] opinions, especially those he articulated towards the end of his life. (...) [He - W.L.] got embroiled in the cultural war having been waged in Poland for two decades. (...) It must be noted here that Herbert's presence sometimes smacks of a comedy of errors, not infrequently confected by enthusiasts of this poetry. (...) [He - W.L.] was fully cognizant of the fact that some values we cherish are often hardy reconcilable, if not mutually exclusive, and on a collision course" (M. Zaleski, "Herbert - trickster" [in:] Nagta wyspa. Studia i szkice o pisarstwie Zbigniewa Herberta, ed. P. Próchniak, Lublin 2015, pp. 17-19).

${ }^{6}$ Comp. A. Zagajewski, "Wiersze Herberta, które lubię najbardziej” [in:] A. Zagajewski, Poezja dla początkujących, Warszawa 2017, pp. 140-143.

7 Z. Herbert, Labirynt nad morzem, Warszawa 2000; idem, Węzet gordyjski oraz inne pisma rozproszone 1948-1998, ed. P. Kądziela, Warszawa 2001; P. Kądziołka, 'Mistrz z Delft' i inne utwory odnalezione, ed. B. Toruńczyk, with collab. H. Citko, Warszawa 2008; H. Citko, Gtosy Herberta, ed. B. Toruńczyk, Warszawa 2008; Herbert nieznany. Rozmowy, ed. H. Citko, Warszawa 2008. 
Initially, the very beginnings of Herbert's artistic presence were shrouded in the mist of history; if the early works were known to the public, that familiarity would have been restricted and fragmentary. The situation has changed by now, as, in this day and age, as opposed to the historical context in which the works originated, we are becoming privy to the origins of the literary career at hand. The publication of Herbert's 1956 debut collection of poems Chord of Light had an eclipsing effect on all his earlier artistic attempts, and the over30-year-old artist came across to his readership as an accomplished writer with a mature artistic identity. ${ }^{8}$ All that notwithstanding, the fact remains that such literary output was not yet considered in its own right, and was put into the indiscriminate blanket category designated for budding artists. ${ }^{9}$ The critical acclaim granted to Chord of Light privileged this collection only to the same extent to which other "promising" debuts were recognised. There was one exception, however, as Kazimierz Wyka critiqued the volume in a separate review essay. ${ }^{10}$ However, more critics engaged with Hermes, Dog and Star, the next collection of poems, released one year later, and this time, the list of reviewers was graced by such names as Anna Kamieńska, Jerzy Kwiatkowski and Ryszard Matuszewski, to name some of them. ${ }^{11}$

As for the 1961 Study of the Object and the 1969 Inscription collections, they definitely gained traction with the public. The poet asserted himself and established his position as a classicist, even though it was noticeable to readers that the tenor of the poems engaged with other dimensions as well. In the case of Barbarian in the Garden, released in 1962, the reading public responded with even more involvement. One may half-joke that the poems unleashed a general groundswell of debate over who should really be branded "a barbarian." Those who in the aftermath of WWII's catastrophic ravages and equally miserable peace accords found themselves corralled behind the Iron Curtain registered a deep yearning to revert to the very wellspring of great art. According to Roman Zimand, "the barbarian in the garden is someone who creates and then ruins the garden of culture, where the transient-eternal capacity for

${ }^{8}$ See: E. Balcerzan, "Arkadyjczyk w oblężonym mieście (O poezji Zbigniewa Herberta)," Twórczość 1986, no. 10, pp. 39-40. See also J. Błoński, "Zbigniew Herbert” [in:] Poznawanie Herberta, selected and foreworded by A. Franaszek, Kraków 1998, p. 22, orig. print.: Życie Literackie 1955 , no. 51, p. 5.

9 Comp. J. Łukasiewicz, "Zbigniew Herbert i rok 1956" [in:] Herbert nieoswojony, ed. W. Browarny, J. Orska, A. Poprawa, Wrocław 2008, pp. 37-38.

${ }^{10}$ K. Wyka, "Składniki świetlnej struny," Życie Literackie 1956, no. 42, reprint [in:] idem, Rzecz wyobraźni, Warszawa 1959, pp. 238-249 (1 $1^{\text {st }}$ ed.).

${ }_{11}$ A. Kamieńska, "Niewierny Tomasz i świat," Twórczość 1957, no. 10-11, pp. 153-156; J. Kwiatkowski, "Klerk mężny," Życie Literackie 1957, no. 40, pp. 4, 9, reprint.: "Imiona prostoty" [in:] idem, Klucze do wyobraźni, Warszawa 1964, pp. 265-279, in this version, the article applies also to Study of the Object, R. Matuszewski, "Wiersze piękne i rozumne" [in:] idem, Doświadczenia i mity, Warszawa 1964, pp. 348-352, orig. print.: Nowa Kultura 1957, no. 48, p. 6. 
containing chaos is evinced by the presence of masterpieces." 12 That notwithstanding, such aesthetes' paradise was out of bounds for Herbert, as he could not banish the memories of evil history or renounce his ethical agenda; additionally, he could not come to terms with the yawning chasm isolating the realm of what was accidental and changeable in an individual biography from the unattainable perfection of consummate artistic achievements.

Even though Zbigniew Herbert had already made a name for himself as an artist and gained many accolades, he did not reach the pinnacle of his career until 1974, when he was 50 years old, and that accomplishment came courtesy of the release of a collection of poems entitled Mr. Cogito. The high artistic esteem and recognition for ethical uprightness earned in the process was in no way diluted by the release of the next collection, entitled Report from a Besieged City; the poems were published in 1983 and they proved to be the most important collection of the period when Poland was in the throes of martial law. As far as $\mathrm{Mr}$. Cogito was concerned, its drift was believed to encapsulate the catechism for Poles striving to reclaim freedom, yet the poet never claimed that the moral precepts it comprised applied to any specific temporal framework. ${ }^{13}$ Still, the possibility of a time-specific interpretation was self-evident, given that the poem became a commemoration and "recompense" for all those fighting and suffering during the time of martial law. ${ }^{14}$ When civic freedoms in Poland were suppressed under the thumb of censorship, Herbert's poems were published by Paris-based Culture and subsequently reprinted as part of underground publishing activities. The subjugated country was portrayed as a collective nightmare (Mr. Cogito returns to "the stony lap/ of his fatherland [to - W.L.] the treasure house/ of all misfortune"), ${ }^{15}$ and yet Herbert's poems, suffused with the message of inner freedom, afforded the blessing of keenly desired hope.

Elegy for the Departure, released in 1990, not unlike Mr. Cogito, was a veritable literary landmark. That point marked the transition to the stage where Herbert's poems were interpreted on the metaphysical plane, ${ }^{16}$ where we can

${ }^{12}$ R. Zimand, "Ogród i barbarzyńca" [in:] idem, Czas normalizacji. Szkice czwarte, London 1989, p. 59.

${ }^{13}$ See A. Nasiłowska, "Zbigniew Herbert: Pan Cogito ma kłopoty" [in:] Sporne postaci polskiej literatury wspótczesnej. Kontynuacje, ed. A. Brodzka, L. Burska, Warszawa 1996, pp. 24-25.

${ }^{14}$ A. Michnik, "Potęga smaku" [in:] idem, $Z$ dziejów honoru w Polsce. Wypisy więzienne, Paris 1985, p. 264.

15 Z. Herbert, "Pan Cogito - powrót" [in:] idem, Wiersze zebrane, ed. R. Krynicki, Kraków 2008, pp. 457-458 (all translations of Herbert's poetry come from: Zbigniew Herbert, Collected Poems 1956-1998, trans. A. Valles, New York 2007).

${ }^{16}$ According to Marta Wyka, "This brand of metaphysics is rooted in a profound sense (...) of the transience of the individual shape of the world. Herbert's journeys morph into journeyings destined for emptiness, heading for the end and ultimate death" (M. Wyka, Herbertpoeta metafizyczny [in:] eadem, Niecierpliwość krytyki. Recenzje i szkice z lat 1961-2005, Kraków 2006, p. 146, first printed Tygodnik Powszechny 1990, no. 32). The tradition of reading Herbert 
discover a poet who juxtaposes allegiance to early initiations, invoked in an elegiac tone, in tandem with musings on ultimate destinies. The two following volumes, Rovigo and Epilogue to a Storm, both released in 1992, struck a chord with very enthusiastic circles of literary critics, whose comments were particularly emphatic of the presence of motifs of grief, bereavement, departure, and brooding preoccupation with death.

The last of Herbert's volumes, Epilogue to a Storm, reverberates with a fusion of autobiographical themes interspersed with existential meditations. What feels palpably poignant here is the language of anguish. However, the plangency of the lament over painful physical agony is counterpointed with soothing eschatological meditations. Loyalty, memory, and conscience are intertwined to form the fabric of life, investing human experience with profound meaning. Therefore, it is fitting here to supply a number of other epithets to characterise the artist: a poet of suffering, the restorer of the elegiac style, a creator of utterances addressing ultimate experiences. When the poet suffered a recrudescence of his disease, the popularity of his legacy was visibly resurgent. Herbert's books "were a hot commodity, [and - W.L.] that phenomenon was paralleled by a spike in the number of treaties examining his output." 17

Over the course of time, the work under discussion was incrementally gaining in significance, searing a lasting imprint on the collective consciousness. It is also worth noting that the scholarship accruing around this poetry exhibited diversification of focus, leading to the emergence of the multifaceted nature of Herbert's poetry and giving more legitimacy to the sentiment that the perception of this literature was truly heterogeneous and multi-aspectual. From the very outset, Herbert's literary production was critiqued and reviewed by the most distinguished Polish literary critics and literary theorists, ${ }^{18}$ such as Kazimierz Wyka (Sktadniki struny świetlnej, 1956), Jerzy Kwiatkowski (Imiona prostoty, 1963), Jan Błoński (Tradycja, ironia i gtębsze znaczenie, 1970), Janusz Sławiński (Tren Fortynbrasa, 1963), Jan Józef Lipski (Między historia i Arkadia wyobraźni, 1962), Jacek Łukasiewicz (Studium przedmiotu, 1963), and Jarosław Marek Rymkiewicz (Krzesto, 1970). Additionally, that list should be extended by later texts, so instrumental in furthering elucidation of Herbert's image: Edward Balcerzan's Arkadyjczyk w oblężonym mieście (1986), Stanisław Barańczak’s O czym myśli Pan Cogito (1974), Tomasz Burek's Herbert - linia wierności (1984), Krzysztof Dybciak's W poszukiwaniu istoty i utraconych wartości (1978),

along the lines of metaphysics is discussed by M. Mikołajczak, Pomiędzy końcem i apokalipsą. O wyobraźni poetyckiej Zbigniewa Herberta, Wrocław 2007, pp. 7-13.

17 J. Hartwig, "Pakiet listów" [in:] Upór i trwanie. Wspomnienia o Zbigniewie Herbercie, ed. K. Szczypka, Wrocław 2000, p. 27, reprint [in:] Wierność. Wspomnienia o Zbigniewie Herbercie, select. and ed. A. Romaniuk, Warszawa 2014, p. 180.

18 The period of reception spanning the appearance of early critical works and the arrival of "ethos interpretations" is examined by A. Franaszek, "Wstęp" [in:] Poznawanie Herberta, op. cit., pp. 8-14. 
Ryszard Przybylski's Między cierpieniem a forma (1978), and Marian Stala's Rok 1983: Gtos poety (1983). The release of Elegy for the Departure marked another distinctive period in Herbert's reception, prompting the publication of the following critical studies: Marta Wyka’s Herbert - poeta metafizyczny (1990), Jacek Brzozowski's Antyk Herberta (1992), Przemysław Czapliński's Śmierć, czyli niedoskonatość (1995), Aleksander Fiut's Jezzyk wiary i niewiary (1993), and Piotr Śliwiński’s Poezja, czyli bunt (1995).

Given the profusion of substantial studies shedding more light on, and stimulating further reflection on, Herbert's legacy, it does not seem feasible to take note of each and every publication belonging either to the cohorts presented above or pertaining to the subsequent years. ${ }^{19}$ In this respect, arbitrariness is, to a point, an ineliminable drawback. Yet the scope of this study also necessitates the explicit acknowledgement that the impressive 1956-2017 period of critical reception, spanning the six decades of Herbert's poetry, essay-writing, and dramaturgy, has spawned other, numerous critical works by both critics and literary theorists, such as Stanisław Balbus, Zbigniew Bieńkowski, Karl Dedecius, Janusz Drzewucki, Elżbieta Feliksiak, Krzysztof Karasek, Andrzej Lam, Anna Legeżyńska, Zdzisław Łapiński, Włodzimierz Maciąg, Janusz Maciejewski, Ryszard Matuszewski, Arent van Nieukerken, Ryszard Nycz, Krystyna Pisarkowa, German Ritz, Artur Sandauer, Marian Stala, Piotr Śliwiński, and Adam Zagajewski.

\section{A rich library catalogue}

Our introductory reflections are now transitioning to another segment, focusing on books profiling Zbigniew Herbert's output. Even though the artist had debuted in 1950, a comprehensive study critiquing his output was not to see the light of day until 1982, when Andrzej Kaliszewski released his Gry Pana Cogito. The author of that landmark, inaugural monographic work did not succumb to the default method of interpretation predominating at that time in Soviet-oppressed Poland; instead, he strove to discern allusions to myths, as well as contextualising Herbert's artistic sensibility against the backdrop of broader literary traditions and aspiring to prospect for hallmarks of neoclassicism in the artist's poems. ${ }^{20}$ Yet the stature of the book was partly overshad-

${ }^{19}$ For a catalogue detailing Herbert's works, see. P. Kądziela, Twórczość Zbigniewa Herberta. Monografia bibliograficzna, vols. 1-2, Warszawa 2009.

${ }^{20}$ This subject is further discussed by A. Kaliszewski, "Klasycyzujący antyklasyk (Zbigniew Herbert)" [in:] idem, Nostalgia stylu. Neoklasycyzm liryki polskiej XX wieku w krytyce, badaniach i poetykach immanentnych ( $w$ kontekśsie tradycji poetologicznej klasycyzmu), Kraków 2007. Piotr Śliwiński underscores the polarization of Herbert's poetics, as both clacissistic and avant-garde features are found in his poems; Śliwiński writes: "the affinity of classicism and avant-gardism 
owed by Stanisław Barańczak's Uciekinier z Utopii (A Fugitive from Utopia), whose first edition was published in 1984. This time, the author emphasised the antinomian aspects of Herbert's thinking, the patterns underpinning his ironic diction along with its varieties and functions. In addition, Barańczak explored the extent to which the poems' subjects and messages were anchored in ethical values. Since the book was published in the USA, out of reach of communist Poland's censorship, there was no need for prevarication regarding the portrayal of Herbert's struggle with totalitarian oppression. As if in passing, Barańczak debunked the misconceptions pertaining to the enthusiastic occidental-centric sentiment, and demonstrated that the annexation of Herbert's output to the goals espoused by classicism was only partial, as none of those categories deserved legitimate absolutisation. And this is how Herbert himself, if self-mockingly, characterised Barańczak's take on him, with the observation possibly lending itself as a succinct and relevant review of $A$ Fugitive from Utopia: "the frog feels beholden to you for leading it out of the classicist desert, for helping it restore sensuous imagination, recognizing its dislike of sermonising, hatred of utopia, and aptly classifying it between the polarities of heritage and deracination." ${ }^{21}$

In the last decade of the $20^{\text {th }}$ century, there was a surge of interest in Herbert's works, giving rise to the appearance of many monographic studies, whose focal point privileged poems and essays. To illustrate the trend, let us single out new additions to the lineage of seminal attempts at "overviews and close-ups": Danuta Opacka-Walasek's '...pozostać wiernym niepewnej jasności.' Wybrane problemy poezji Zbigniewa Herberta and Marek Adamiec's '...Pomnik troche niezupetny...' Rzecz o apokryfach i poezji Zbigniewa Herberta; both works were released in 1996. Opacka-Walasek's vantage point postulates the coinage of a new critical category, namely that of "establishing new order based on an axio-normative system"; she also concerns herself with other poetic forms of recording memories and with values informing a moralist mindset. Additionally, she exhibits some preoccupation with the issue of the art of travelling. But Adamiec, marginalising the aspect of the poet's influence on society, puts a premium on tracking instances of intertextuality, patently drawing on sacred scriptures, epic tales punctuating the history of culture, historical sources, mythology, and the artistic realms of painting, architecture, and music.

As regards to Piotr Siemaszko's pioneering monographic work on Herbert's essays entitled Zmienność $i$ trwanie, also published in 1996, the study, already

\footnotetext{
would consist in (...) the occurrence of Tyree common denominators: firstly, reliance on premises, programmes, and ground rules, secondly, envisioning the products of the artistic process as action, and thirdly, prioritizing reality and form and treating the personality of the author as secondary" (A. Kaliszewski, "Porywczość formy" [in:] Nagta wyspa..., op. cit., pp. 197-198).

${ }^{21}$ Letter from 6 ${ }^{\text {th }}$ Dec. 1983 [in:] Z. Herbert, S. Barańczak, Korespondencja, ed. B. Toruńczyk, Warszawa 2005, p. 14
} 
in its title, features a contradiction in terms, and this antinomy is addressed within the ontological, the epistemological, and the ethical schemes of things. The researcher demonstrates that, in the face of the destructive instability of nature and the permanence of peril, Herbert's man finds recourse in enclaves of perfect order represented by painted masterpieces. The book combines investigation into the artist's philosophical inspirations with reflections revolving around his art-historic initiations. Yet another emphatic, overriding focus comes to the fore in Andrzej Franaszek's Ciemne źródto (O twórczości Zbigniewa Herberta), published in 1998 - the author analyses the burden of suffering, which cannot be eliminated from human fate, and that is why it must be accepted and comprehended. From this vantage point, the source of other brands of anguish and despair can be identified both in isolated existence in the world and the inalienable yearning for truth. Ciemne źródto is characterised by one more distinct plane of reflection, which is the metaphysical scandal of death; as a result, "humans are ineluctably perceived through the prism of mortality." 22

Another researcher, Julian Kornhauser, has advanced a very interesting and consistent approach to reading Herbert and presented it in his 2001 book entitled Usmiech Sfinksa. A poet, critic, and researcher, Kornhauser set out to turn the spotlight on correspondences between Herbert's poetic creations and his biography, thereby demonstrating that a perusal of the organic chronology of the poems in subsequent collections revealed gradual evolution of key Herbertian themes: from brooding on the trauma of war and searching for reliable pillars of strength in culture, which is evident in Chord of Light, to the final reckoning with life and a writing career in Epilogue to a Storm.

Jacek Łukasiewicz's Herbert, published in 2002, typifies a refined and splendid form of criticism aimed at popularising what transpired after many years of his thorough dissection of Herbert's legacy. ${ }^{23}$ The dynamically unfolding story, never resorting to oversimplification or omission, recaptures the poet's private life and the most prominent aspects of his literary pursuits. The biography is vividly rendered into a tale, with chapters on his years spent in Lwów, which

22 A. Franaszek, Ciemne źródto (o twórczości Zbigniewa Herberta), Londyn 1998, p. 165. Franaszek's book coincides with "the period when research into the topic of Herbert's attitude to life and death was in its nascency. The investigative range for such endeavours was circumscribed by Ryszard Przybylski in his essay "Między cierpieniem a formą" [in:] Poznawanie Herberta, op. cit. See also P. Czapliński, Śmierć, czyli o niedoskonatości [in:] Poznawanie Herberta, op. cit., pp. 280-303; P. Panas, "Herbertowe 'ars moriendi"” [in:] Wyraz wytuskany z piersi. Szkice o twórczości Zbigniewa Herberta, ed. B. Gautier, D. Knysz-Tomaszewska, J.M. Ruszar, M. Zieliński, Lublin 2006, pp. 218-230; D. Zawistowska-Toczek, "Droga ku śmierci. Ostatni towarzysze Starca, ostatnie rozmowy i samotność cierpienia” (and foll.) [in:] D. Zawistowska-Toczek, Stary poeta. 'Ars moriendi' w późnej twórczości Zbigniewa Herberta, Lublin 2008, p. 333 and foll.; K. Pietrych, Spotkanie drugie: Zbigniew Herbert [in:] eadem, Co poezji po bólu. Empatyczne przestrzenie lektury, Łódź 2009, pp. 77-104.

${ }^{23}$ We ought to mention a collection featuring a range of interpretations: J. Łukasiewicz, Poezja Zbigniewa Herberta, Warszawa 1995. 
had to be forsaken, and his post-war twists and turns of fortune. The fabric of the book encompasses the themes of the predicament of a man and artist, compassion, travels, mythology, cultural genealogy and the character of $\mathrm{Mr}$. Cogito, history, God and transcendence, infirmity and death. That approach to writing is also evident in Czytajac Herberta by Danuta Opacka-Walasek, published in 2001. The book is prefaced by an instructive introduction, and much as the interpretations are intended for foreign students, the readership of the book definitely extends beyond this target group.

In the course of the meticulously arranged form and content of Małgorzata Mikołajczak's W cieniu heksametru. Interpretacje wierszy Zbigniewa Herberta, published in 2004, the author explores the significance of allusions to, and variations on the theme of, the antique tonic hexameter. Furthermore, she points to the vast common ground allowing for references to literary tradition and dialogue with Polish poets. The verse form is inextricably bound up with the semantics of the poetic expression. This method of presentation does justice to Herbert's aesthetic preferences and his predilection for lofty turns of phrase, but also for his classicistic sensibilities. In his assessment of the above publication, Piotr Michałowski neatly encapsulated its very essence - "six feet of culture." 24

Ranking among the most illustrious experts on Herbert's poetry, Małgorzata Mikołajczak systematically expands the scope of her explorations. Her 2007 monograph bearing the title Pomiędzy końcem i apokalipsą. O wyobraźni poetyckiej Zbigniewa Herberta should be viewed as the summa of the descriptions of the poetic world of the author of Epilogue to a Storm. She decides to take inventory of the field of Herbert criticism, cataloguing various conceptual approaches to reading the poet. The pride of place in her evaluation is given to "the poet's metaphysical imagination conceived of as a sphere of ideation synthesising space, time and the remaining elements of the world represented in relation to metaphysical aspects of existence." 25 This catalogue of the component tropes of our imagination comprises, among others, relics of a catastrophe and visions of the end; moreover, in the case of these two categories, allusions to the poets representing the second avant-garde and those of the WWII generation achieve particular significance. Additionally, the list of important building blocks of our imagination includes elements of the long tradition of myth from the Bible to the Orphic myth, motifs of redemptive art, pictorial tokens of a miserable spell of history, poetic renditions of immobile space, temptations of nihilism, imaginings associated with a possible or impossible belief, as well as a sensibility exhibiting strong affinities with the Eliotesque waste land.

Authored by this academic is another critical work - Swiaty $z$ marzenia, where Herbert's poetic output is projected against the backdrop of three

${ }^{24}$ A monograph by Michałowski bearing this title appeared in Rzeczpospolita (2004, no. 241).

${ }^{25}$ M. Mikołajczak, Pomiędzy końcem i apokalipsq..., op. cit., p. 37. 
frameworks of reference: the Shakespearan, Norwidesque, and Polish-Romantic traditions, respectively. Employing the metaphor of a broken Orphic lyre, and trying to reaffirm the belief in the possibility of reconstituting order in the world by means of words, Mikołajczak writes about intertextual dialogue with the fundamental tradition underlying Polish literature, namely that dominated by the motifs of prophetism and the struggle for freedom. Almost in the same breath, she emphasises that Herbert's ironic diction is also characterised by "negative perception of attitudes and persuasions stereotypically associated with Romanticism." 26 The publication is all the more inspiring due to the author's observations on the significance of the musicality pervading Herbert's poems, the establishment of correlations between art and ethics, the metamorphic nature of Romantic motifs, and the "patronage" exerted by the seminality of Hamlet and Shakespeare at large. Furthermore, due to the inclusion of interpretations of pieces from Utwory rozproszone, the publication proves invaluable in that it sheds new light on the cultural legacy of the past.

Of course, I can but confine myself to the most notable contributions to unravelling Herbert's knot. ${ }^{27}$ The next evolutionary stage of criticism, which I have already alluded to, had to do with systematic research conducted in the world of academia, and such activities were invariably extensively assisted by cultural institutions. We should not omit to mention here the great number of sessions, workshops, and meetings enhancing the integration of researchers hailing from diverse academic milieus. In the process, new book releases were characterised by a palpably pronounced specialised slant - the impress of theory was stronger than ever before. And, par for the course, such initiatives led to the emergence of collective works. ${ }^{28}$

Having commented on the new developments above, we also ought to mention the significant part played in that period by the editorial series entitled "Biblioteka Pana Cogito," which commenced in 2004. Comprising both individually-authored and collective works, the series expanded the scope of reflection by annexing new philosophical and aesthetic perspectives and by

${ }^{26}$ M. Mikołajczak, Światy z marzenia. Echa romantyczne w poezji Zbigniewa Herberta, Zielona Góra-Kraków 2013, p. 72.

${ }^{27}$ I confine myself merely to a mention in passing of this comprehensive publication by Bogdan Urbankowski, Poeta, czyli cztowiek zwielokrotniony. Szkice o Zbigniewie Herbercie, Radom 2004. On the whole, this critical enterprise is an impressively ambitious project with respect to its informative and exploratory merits, as the author is trying to put together a very detailed monograph; however, it has some demerits, as the author usurps the authorship of some observations, formulates deprecatory opinions on the virtue of documented research, and displays a discourteous, trenchant attitude that does not befit such a publication.

${ }^{28}$ Czytanie Herberta, ed. P. Czapliński, P. Śliwiński, Poznań 1995; Twórczość Zbigniewa Herberta, ed. M. Woźniak-Łabieniec, J. Wiśniewski, Kraków 2001; Herbert i znaki czasu. Colloquia Herbertiana, ed. E. Feliksiak, M. Leś, E. Sidoruk, vol. 1, Białystok 2001, vol. 2, Białystok 2002; Herbert. Poetyka, wartości i konteksty, ed. E. Czaplejewicz, W. Sadowski, Warszawa 2002; Niepewna jasność tekstu. Szkice o twórczości Zbigniewa Herberta 1998-2008, ed. J.M. Ruszar, Kraków 2009. 
adding new contexts for the evaluation of the poetic production under discussion. In addition, it must be observed that the aforementioned vibrant critical and research activity was earmarked by a generational change of the guard, as young authorities on Herbert managed to find their voice and asserted themselves, which was tellingly evidenced by new collective works, such as Czutość dla Minotaura (2005), Dialog i spór (2006) and Pojęcia kietkujace z rzeczy (2010). That enumeration could be extended by the somewhat related anthology of interpretations entitled Gaszcz srebrnych liści (2015) and collective publications Literature and Phenomenology. Zbigniew Herbert i Tadeusz Różewicz w kręgu myśli Ingardenowskiej (2016). Furthermore, there have been individual critical attempts, and the list of those meriting explicit acknowledgement should include Anna Mazurkiewicz-Szczyszek's W asyście jakich dzwonów. Obrazy miasta w twórczości Zbigniewa Herberta (2008), Dagmara Zawistowska-Toczek's Stary poeta. 'Ars moriendi' w późnej twórczości Zbigniewa Herberta (2008), Mateusz Antoniuk's Otwieranie gtosu. Wczesna twórczość Zbigniewa Herberta (1948-1957) (2009), Między nami a świattem. Bóg i świat w twórczości Zbigniewa Herberta (2012), and Magdalena Śniedziewska’s Wierność rzeczywistości. Zbigniew Herbert o postawie wobec świata i problemach jego reprezentacji (2013). That last publication is envisioned as an album showcasing the reproductions of the works of art alluded to by the author of Still Life with a Bridle.

One of the key driving forces behind the development of the Herbert-centred awareness-raising movement has been Józef Maria Ruszar. This researcher of Herbert's output has made significant contributions in that he has been an organiser of academic conferences, run Herbert-themed workshops (Warsztaty Herbertowskie) for aspiring theorists of literature, originated the idea and served as editor-in-chief of "Biblioteka Pana Cogito," and created the Internet Herbert.guru portal, of which he has been the editor. He has also published numerous books: Stróż brata swego. Zasada odpowiedzialności w liryce Zbigniewa Herberta (2004), Stońce republiki. Cywilizacja rzymska w twórczości Zbigniewa Herberta (2014), and Wytarty profil rzymskich monet. Ekonomia jako temat literacki w twórczości Zbigniewa Herberta (2016). The titles of these books alone speak volumes about their thematic range, extending from ethical-philosophical matters to civilizational issues, to historical-cultural considerations, as well as various disciplines of knowledge, such as historiosophy or conceptions of economic development. ${ }^{29}$ What is more, all of these allusions are interspersed with references to literary tradition, mainly that bequeathed by Romanticism. The point of departure for the third of the books presented above is set in ancient Greece and Rome, and the content, as such, is focused on economics. Only at first blush may it appear to be a peripheral interest cultivated by Herbert, as he actually possessed credentialed expertise in that field. Thus, obviously, such a background peeked through in

29 J.M. Ruszar, Stońce republiki. Cywilizacja rzymska w twórczości Zbigniewa Herberta, Kraków 2014, p. 19. 
and fuelled his poetry and essay writing; moreover, it enriched his imagery, lent itself as metaphor material, as well as enhanced clarity and helped understanding. Here, Herbert comes across as an expert sui generis, an aficionado and critic of economic and financial matters pertaining to many centuries of European history.

In recent years, we have been observing the predominance of monographic works, turning the spotlight on just one selected subject from the spectrum of Herbert's artistic activity. These investigations and dissections centre on such issues as the definition and delineation of the sacred, painting, the city, senility, aesthetic persuasions, artistic philosophy, and broadly conceived dialogue with philosophical schools. Moreover, we ought to make mention of Herbert's deployment of humour as a tool for facilitating comprehension. Researchers are trying to tackle the issue of how the established common cultural denominators are refracted by Herbert's prism of perception, and, at the same time, they are striving to answer the question of how this culture-related reading of Herbert can reveal his unique character. Another issue under investigation is whether his juvenile productions actually illuminate the poet's mature accomplishments. Still, the ever-increasing abundance of critical works commenting on Herbert's legacy renders it impossible for the compass of one article to address all dimensions of this material.

\section{Four overviews}

I have elected to focus on four examples of publications characterised by varied thematic fields and informed by different research methodologies. Such a quality of unique variety materialises courtesy of the inclusion of the four works profiled below. Firstly, "genetic criticism," which can be defined as reflections on the development of Herbert's writing skills and buttressed by meticulous analysis of the poet's manuscripts (Mateusz Antoniuk's Otwieranie gtosu. Studium o wczesnej twórczości Zbigniewa Herberta (do 1957 roku), 2009). Secondly, I have chosen Jolanta Dudek's Granice wyobraźni, granice stowa, investigating the presence of Western references in Herbert's legacy. Thirdly, I look at studies from the field of comparative literary research focusing on the $20^{\text {th }}$ century (I discuss an extensive study, or even a moderate monograph, entitled Zbigniew Herbert wobec T.S. Eliota, 2008), illustrating the orientation of aesthetic-philosophical interpretation and having bearing on the discussion of the condition of art when belief in redemption through beauty is eroding (Karol Hryniewicz, Cogito i dubito. Dyskurs estetyczny w poezji Zbigniewa Herberta i Tadeusza Różewicza, 2014). The fourth study is illustrative of specific employment of comedy and humour, and it expands on the function of the attitude of facetiousness tinged with irony (Agnieszka Kramkowska-Dąbrowska, Gabinet luster. Śmiech w twórczości Zbigniewa Herberta, 2015). 
Emerging from Mateusz Antoniuk's book is a multi-faceted "portrait of an artist as a young man," who is developing his creative awareness, seeking validation for espoused values, and resisting the temptations of the propaganda of the 1950s. What is more, the young artist is elaborating a strategy for his creative debut and dreaming of coming into his own and achieving artistic independence. The survey of the archives accomplished by Antoniuk did bear fruit, and, certainly, his emulators will be taking a leaf out of his book for years to come. This publication demonstrates the forms and major goals of the artistic pursuits undertaken by young Herbert. Unless we are privy to the unpublished works, we cannot bring to light the specificity of his developed writing skills, and, therefore, the mature works may still guard part of their mystery. It makes for a wonderful read to be able to trace back the course of a biography and see how and when a debuting poetic non-entity metamorphosed into a sought-after and admired poet.

The periodisation of Herbert's artistic activity presented in Otwieranie gtosu entails the examination of a succession of means of expression in different literary forms and genres. The author adopts a multi-pronged approach to presenting the material, which is visible in the presence of comparative considerations, reflections on the employment of poetic language, perusal of texts, and reports on a survey of the poet's archives. Let us highlight two narratives relating to the inchoate stages of Herbert's activity: the first one concerns Herbert's "creation myth," repudiating any dependence on the poets belonging to the WWII generation, and the other pertains to the stylised spiritual journal revealing the inauguration of that new profile of creativity (by that time Herbert's Journal métaphysique had not come to light). Another attempt at finding his own poetic voice can be noticed in his translation of Reiner Maria Rilke's Autumn Day; the translation itself is subjected to exquisite analysis by Antoniuk.

One of the key premises serving as a beacon for Antoniuk's explorations can be encapsulated as follows: "It is both possible and desirable to portray Zbigniew Herbert's artistic output as an experimental testing ground, where specific genres of literature weave in or out of existence, complement or compete with each other, put down roots or just put in an appearance." ${ }^{30}$ In this critical material, Herbert is portrayed as a writer meditating on man's place in the world, on his identity and the gradual process of self-discovery and individuation. In each and every one of the genres he experimented with, this introspection followed different paths: for example, in the early, post-WWII prose works, the dissolution of the heroes' personalities is so profound that the subject degrades to the level of the object. In the dramatic work entitled Cave of Philosophers, by contrast, the riddle of being a unique, separate entity is, to an extent, selfrevealing, as the hero is besieged by a multiplicity of his own images. Mateusz

${ }^{30}$ M. Antoniuk, Otwieranie gtosu. Studium o wczesnej twórczości Zbigniewa Herberta (do 1957 roku), Kraków 2009, p. 97. 
Antoniuk writes about the diminution of authorial perspective and notes that the ultimate emergence of Mr. Cogito would arguably have been a foregone conclusion given the expansion of the role played by lyrical expression.

In view of the above observation, special attention should be given to the fragment dealing with Herbert's short prose works, as they are dubbed here "poetic palimpsests written in prose." 31 The author of this critical disquisition reflects on the extent to which the grand epic form would have represented a challenge to Herbert. In fact, all this critic had at his disposal were barely a couple of preserved pages of a "novel about time." In the following chapters, Antoniuk revisits the notebooks from the Herbert archives, first, throwing light on the evolution of the lexical dimensions of texts, second, surveying the organic development of artistic elaboration originating from preliminary literary thumbnail sketches and, finally, critiquing alternative versions. Thanks to his knowledge and imaginativeness, the researcher can proceed in lockstep with the poet's decisions in his own creative process, even to the point of re-enacting them, in a way.

As regards Jolanta Dudek's Granice wyobraźni, the author uses the examples of Herbert and Różewicz to illustrate the complex mechanism whereby Polish poetry was susceptible to the influence exerted by salient modernistic poetic movements, i.e. transposed symbolism, imagism, vorticism, and neoclassicism. The structure of the work follows the dual-track narrative pattern, addressing both Polish and English-language literary traditions, aesthetic values, philosophical messages, artistry, and correlations between art and historical time. In the process, we come to the important realization that the poetic outputs of both Zbigniew Herbert and Tadeusz Różewicz can successfully hold their ground in confrontation with masterpieces of world literature. Furthermore, Dudek notes differences pertaining to the understanding of concepts and idiosyncrasies of mentality and cultural conceptions in Poland and in the Western world. Additionally, some attention is paid here to the nature and presence of time lag in terms of the transfer of innovative ideas infiltrating Polish literature from abroad. For the sake of such juxtapositions, the author sets her agenda and methodology in a perfectly plausible way: emphasis is placed on the criteria for analogies, translations, transpositions and conceptual consonance.

Central to the aforementioned presentation are issues relating to memory and imagination. Both of these dimensions of meaning identified in Eliot's and Herbert's poems are contextualised by the author in the philosophical tradition originated by Blaise Pascal in his Pensées. ${ }^{32}$ Moreover, the juxtapositions of the two poets are immersed in the conception of imagination defined as "unified

31 Ibid., p. 132.

32 J. Dudek writes that "Mr. Cogito's imagination is predisposed to (...) the perception and creation of a protocol for compassion that runs counter to the order that Pascal advocates in dealings with individuals whose attempts to find invisible God have been to no avail" (J. Dudek, Granice wyobraźni, granice stowa. Studia z literatury porównawczej XX wieku, Kraków 2008, p. 38). 
sensitivity," ${ }^{33}$ ensuring the integration of the subject of expression. Furthermore, the two aspects are confronted with historical thinking as well as with the discourses of empathy and loyalty. Finally, they are analysed through the prism of modernist objectification of feelings and anthropological diagnoses regarding passive indolence and wishful thinking. With impressive facility and expertise, the author navigates the realms of modern literature and philosophical contexts contemporary to both writers, respectively. The affinities and parallels enumerated above are demonstrated through cross-referencing specific poetic works by T.S. Eliot and Zbigniew Herbert (from 1983 to 1998). The following are just examples of such comparative couplings: Eliot's "Four Quartets" and Herbert's "Mr. Cogito and the Imagination," Eliot's "La Figlia che piange" and Herbert's "Tenderness" as well as "Flowers," Eliot's "Ash Wednesday" and Herbert's "To Ryszard Krynicki - A Letter."

As far as Karol Hryniewicz's Cogito i dubito. Dyskurs estetyczny w poezji Zbigniewa Herberta i Tadeusza Różewicza (2014) is concerned, we witness a shift in terms of the focus of critical scrutiny. Thrown into stark relief in this book are both the significance of a theoretical framework enabling the explication of aesthetic considerations in Herbert's and Różewicz's poems, and poetic discourses having some bearing on that kind of approach as well as being conducive to comprehending late modernity. The author describes ways in which the two poets conceive of modern art, and embarks on a reflection on idioms, images, concepts and various forms of debate with modern aesthetics encountered in works by these two outstanding 20th-century Polish poets. In addition, Hryniewicz seeks out and explores echoes of conceptions comprising conventional wisdom regarding art as such; of course, such notions are invariably filtered through unique, poetic sensibilities.

When it comes to the process of the aggregation of Hryniewicz's lexicon of conceptual tropes, it was significantly influenced by Charles Taylor's "imaginaries"; it must be noted that the premises of that book were outdone, invalidated, or contradicted by the experiences of the WWII generation (this sentiment relating to Różewicz and Herbert is expressed by the Canadian philosopher in Sources of the Selff). Hryniewicz's investigation sets great store by the notion of "aesthetic situation" and by attempts at aesthetic evaluation. In his book, he writes: "Herbert's outlook on art and aesthetics is determined by (...) his adoption of an axiological stance. The poet's penchant for objectification (...) implies (...) an essentialist attitude to art, i.e. a conviction of its universal and timeless nature."34 In this context, we need to give some prominence to the subject-praxis-art triad applied in the aesthetic discourse. Among numerous observations prompted by this perspective, the most conspicuous are attempts to demonstrate commonalities

${ }^{33}$ Ibid., p. 41 and foll.

${ }^{34}$ K. Hryniewicz, Cogito i dubito. Dyskurs estetyczny w poezji Zbigniewa Herberta i Tadeusza Różewicza, Kraków 2014, pp. 85-86. 
between Herbert's poems and Friedrich Schiller's On the Aesthetic Education of Man, with the emphasis placed on the therapeutic and instructively edifying role of aesthetics, interpersonal relations based on aesthetic values, historiosophy, and politics. Next, the author draws a comparison between Herbert's reflections on taste and Anthony Ashley Cooper Shaftesbury's thoughts on ideas. Finally, under this rubric, we can highlight Hryniewicz's original observations regarding "the figure of a precipice" and the figure of chasm. Other interesting contentions of correspondence can be found in the chapter entitled "Najpiękniejszy jest przedmiot, którego nie ma' - o estetycznej funkcjonalizacji kategorii braku," where the author draws parallels between Herbert's conception of art with the ontology of value espoused by Elzenberg, chief among which is the discussion of the status of beauty according to the latter doctrine.

Our reconstructive attempts would not do full justice to the profile of Herbert's writing if we overlooked the presence of poetic humour. Julia Hartwig distinguishes many brands of humour, both in Herbert's life and writing, and they can be exemplified by "casual humour, ironic humour, and sarcastic humour." 35 Thus, apparently, in order to redress that humour-related lacuna in studies in the field of literary theory, Agnieszka Kramkowska wrote Gabinet luster. Smiech $w$ twórczości Zbigniewa Herberta. Of course, both academically and critically, there had been some allusions to such poetic humour, ludic hilarity, and grotesquery before, but the references had been incidental. Now, such subject matter is brought to the fore, and the end result is impressively informative. Agnieszka Kramkowska-Dąbrowska describes multifarious and fluctuating communicative scopes of laughter in Herbert's artistic activity. What merits special recognition here are subtle confluences of humour and philosophical thinking, as well as contrasts between the style and the subject matter of the utterance. Furthermore, there are references to the tensions between an infantile attitude to the world and mordant, unmasking irony. Thus, the book Gabinet luster brings to the reader's notice, and very aptly and precisely, too, such qualities earmarking Herbert's output; what is more, we are treated to a true rarity in Polish literature, that is, a playful manipulation of the lyrical persona, as well as creative verbal humour.

The subject of laughter in Herbert's output betrays a dynamic, Protean quality, as shown in Kramkowska-Dąbrowska's reflections, where the metamorphosis from a humourist to an ironist to a satirist is presented chronologically. Starting from the inceptive stages, the trajectory of development is bounded by Herbert's attempts to find his literary voice, which was followed by the poet's debut and rise in popularity, the period of mature works, and then the closing stage, namely elegiac and existential meditations, tinged with valedictory overtones leavened with humour. In Herbert's poetry, the presence of varied tones of laughter is associated with literary polyphony, intertextuality, and allusions to "the diction of others." The type of his laughter changes not only in direct

\footnotetext{
${ }^{35}$ J. Hartwig, op. cit., p. 27.
} 
correlation with the constraints imposed by the conventions of the genre, but also in line with the phenomena being addressed. Then, the humorous thrust of Herbert's commentary ranges, on the one hand, from a sense of humour which is by no means disingenuous, to an ambiguous smirk and rebarbative satire targeting some current developments; if it escalates further, it spirals down to a scathing, no-holds-barred brand of irony and grotesquery disfiguring reality. As much as it may be redolent of an oxymoron, there is also such a thing here as serious laughter, which enhances philosophical enquiry, and puts suffering into perspective, albeit without eliminating it. As demonstrated by Kramkowska-Dąbrowska, jocular qualities in Herbert do bear affinities with the language and worldview observed in children. Furthermore, the researcher gives separate, extensive treatment to poetic language, verbal humour, grotesquery, and the common ground it shares with suffering-related and catastrophic brands of narrative. Definitely, the author's claim to fame is the restitution of the satirical streak in Herbert in the consciousness of the reading public.

\section{Texts at close quarters}

Since the poet's death in 1998, we have been witnessing a significant increase in the number of studies in the field of literary theory. We ought to mention here a shift concerning the reception of Herbert's writing from the domain of literary criticism to the realm of literary theory. Thus, intuitions and hypotheses prompted by the "an ear for literature" as well as interpretations warranted by a critical sense of relevance to the current circumstances, have gradually been supplanted by systematic, academic research; the new modus operandi was underpinned by the consciousness of the methods employed. In view of this, one could not overestimate a poetological approach, fortified by genology and the history of forms. To exemplify such a work, it suffices to mention Agnieszka Kluba's treatise, where the discussion of the terminological apparatus is entwined with the history of Herbert's reception pertaining exclusively to his poetic prose, for one thing, and attempts to elaborate a new perspective on works representing that genre, for another. ${ }^{36}$

Quite often the discussion of Herbert's literary production and the comparative frameworks used for such analysis transcend the ambit of literature, necessitating forays into the domains of fine arts and philosophy. What predominates in the most recent reflection on Herbert's artistic legacy are miscellaneous philosophical inspirations, which include pre-Socratic ideas, Nietzschean motifs, or phenomenological considerations; additionally, there is a quest for

${ }^{36}$ A. Kluba, "Zbigniew Herbert" [in:] eadem, Poemat proza w Polsce, Warszawa-Toruń 2014, pp. 477-500. 
the definition of the sacred. There are also attempts at the reconstruction of the dialogue between literature and fine arts, as well as aesthetic premises and references to Herbert's conception of poetry and the poetics of his texts. This list could also be extended to the issues of cultural orientation, which concerns the extent to which Herbert's work is aligned with various discourses generated by society, the unearthing of the role of the body and material objects as well as reflections on subjectivity. We have also observed the initiation of a discussion of how this poetry transmits itself to and inspires next generations of scholars, whose works are also subjected to detailed scrutiny in this book. Of course, I have a duty to mention some works released in the recent years, but the constraints of this study preclude their extensive evaluation. What follows is just a selection of such publications: Joanna Adamowska's Różewicz $i$ Herbert. Aksjologiczne aspekty twórczości (2012), Artur Grabowski's Herbert-Hermes. Konteksty nowoczesności w esejach, dramatach i wierszach Zbigniewa Herberta (2013), Magdalena Śniedziewska's Siedemnastowieczne malarstwo holenderskie w literaturze polskiej po roku 1918 (2014), Mirosław Dzieńs Motywy eschatologiczne w poezji Zbigniewa Herberta. Studium analityczno-interpretacyjne (vols. 1-2, 2014), Katarzyna Wyszyńska’s Sukcesorzy Pana Cogito (2016), Wojciech Ligęza’s Bez rutyny. O poezji Wistawy Szymborskiej i Zbigniewa Herberta (2016), Piotr Siemaszko's, Wehikut poezji i cnoty. Myśl o pięknie w twórczości Zbigniewa Herberta (2016), Roman Bobryk's Koncept poezji i poety w wierszach Zbigniewa Herberta (2017), Jan Księżyk's Znaczenie ekfrazy dla poetyki narracji eseistycznej: formy ocalania wartości doświadczenia piękna w eseistyce Zbigniewa Herberta (2017), Radosław Sioma’s Krzesto i zmięta serweta. Szkice o twórczości Zbigniewa Herberta (2017), as well as collective works. ${ }^{37}$

So far, conspicuously absent from this account have been interpretations of particular poems as such. The multiplicity of interpretations of such items vividly demonstrates that, for one, the calibre of such challenges is very high, and, for another, the inexhaustible richness of the poetic fabric of such works incessantly impels critics to pick up the gauntlet of new approaches. The continuous process of critiquing allows for teasing out and illuminating ever deeper lamina of the poems' semantics. Due to the extended period of the reception of Herbert's poems, the public domain is privy to detailed exegetic analyses. In the case of those popular and highly esteemed poems by Herbert, due to the accumulation of enough critical and academic material, we can speak of the development of exclusive microhistories of interpretation. Certainly, many interpretations have attained memorable status in the memory of both professional, critical circles and among amateur Herbert aficionados at large;

37 See also: Bór nici. Wątki klasyczne i romantyczne w twórczości Zbigniewa Herberta, ed. M. Mikołajczak, Kraków 2011; Między nami a świattem. Bóg i świat w twórczości Zbigniewa Herberta, ed. G. Halkiewicz-Sojak, R. Sioma, Toruń-Kraków 2012; Nagta wyspa..., op. cit.; Pracownia Herberta. Studia nad procesem tekstotwórczym, ed. M. Antoniuk, Kraków 2017. 
unfortunately, the collection of reliable material for a well-documented study would have to run here over a good many pages. Certainly, though, there are classic interpretations, elaborated to the scope of a fully-fledged treatise, reprinted in anthologies and frequently quoted.$^{38}$ Herbert's individual poetic works afford a glimpse into the artistic and conceptual profile of the whole output, but they also invoke broader cultural paradigms resonating with and, by the same token, subsuming newly deciphered poetic statements.

Apparently, there is no end to the accumulation of new takes on given poems, reaching the quantitative stage where interpretations pertaining to a given poem could easily be anthologised. This phenomenon can be clearly seen in the case of the following poems: "Elegy of Fortinbras," 39 "The Envoy of Mr. Cogito," ${ }^{40}$

${ }^{38}$ For example: J. Sławiński, "Tren Fortynbrasa” [in:] Poznawanie Herberta, op. cit., pp. 359-375; S. Barańczak, "Cnota, nadzieja, ironia (Zbigniew Herbert: Pan Cogito o cnocie)" [in:] idem, Tablica z Macondo. Osiemnaście prób wyttumaczenia, po co i dlaczego się pisze, London 1990, pp. 71-85; M. Stala, "W cieniu dębów. Nie tylko o jednym wierszu Zbigniewa Herberta"; J. Łukasiewicz, "Elegia na odejście pióra atramentu lampy" [these three texts] [in:] Poznawanie Herberta 2, op. cit., pp. 381-398, 436-443, 444-456; R. Nycz, "Niepewna jasność tekstu i 'wierność' interpretacji. Wokół wiersza Zbigniewa Herberta 'Pan Cogito opowiada o kuszeniu Spinozy”; D. Pawelec, “Bądź wierny Idź” [„Przesłanie Pana Cogito”] [these two texts] [in:] Niepewna jasność tekstu..., op. cit., pp. 33-55, 75-111.

39 Among others, such works as: S. Dąbrowski, "Hamlet i Fortynbras (między literaturą a rzeczywistościa)," Tygodnik Powszechny 1971, no. 8; A. Kamieńska, "Okrucieństwo mitu” [in:] A. Kamieńska, Od Leśmiana. Najpiękniejsze wiersze polskie, Warszawa 1974; K. Wyka, "Tren Fortynbrasa” [in:] idem, Rzecz wyobraźni, Warszawa 1977 ( $2^{\text {nd }}$ ed.); J. Sławiński, “Tren Fortynbrasa” [in:] Poznawanie Herberta; J. Trznadel, "Kamieniowanie mądrości” [in:] idem, Ptomień obdarzony rozumem. Poezja w poezji i proza poezja. Eseje, Warszawa 1978; D. Opacka-Walasek, "Tren Fortynbrasa" [in:] D. Opacka-Walasek, Czytając Herberta, Katowice 2001; R. Sioma, "Jeszcze raz o "Trenie Fortynbrasa”" [in:] Opis wiersza. Analizy i interpretacje liryki polskiej, ed. R. Sioma, Toruń 2002, reprint [in:] idem, Krzesto i zmięta serweta. Szkice o twórczości Zbigniewa Herberta, Kraków 2017, pp. 11-35; M. Mikołajczak, "Czytać 'Tren Fortynbrasa' do końca” [in:] idem, W cieniu heksametru. Interpretacje wierszy Zbigniewa Herberta, Zielona Góra 2004; J.M. Ruszar, "Racje Fortynbrasa, racje Hamleta" [in:] idem, Stróż brata swego. Zasada odpowiedzialności w liryce Zbigniewa Herberta, Lublin 2004.

40 Again, the enumeration is incomplete: A. Kowalczyk, "Złote runo nicości. 'Przesłanie Pana Cogito' - próba lektury," Tygodnik Powszechny 1983, no. 11; J. Łukasiewicz, "Przesłanie Pana Cogito" [in:] idem, Poezja Zbigniewa Herberta, op. cit., pp. 75-84; A. Nawarecki, "Trzy ostatnie słowa Pana Cogito. O wierszu Zbigniewa Herberta 'Przesłanie Pana Cogito"' [in:] Kanonada. Interpretacje wierszy polskich (1939-1989), ed. A. Nawarecki, D. Pawelec, Katowice 1999; J. Bigaj, "Za przesłaniem Herberta nie pójdę...” [in:] Herbert. Poetyka, wartości i konteksty, op. cit., pp. 165-172; K. Kłosiński, "Poezja zaimków. O 'Przesłaniu Pana Cogito' Zbigniewa Herberta” [in:] Liryka polska XX wieku. Analizy i interpretacje. Seria trzecia, ed. W. Wójcik, J. Kisielowa, Katowice 2005; K. Biedrzycki, "Bez zmartwychpowstania" [in:] K. Biedrzycki, Wariacje metafizyczne. Szkice i recenzje o poezji, prozie i filmie, pp. 93-103; D. Pawelec, "Bądź wierny Idź" [in:] Niepewna jasność tekstu..., pp. 77-111; “'Złote runo nicości.' O 'Przesłaniu Pana Cogito' (...) discussion between Stefan Chwin, Tadeusz Dąbrowski, Andrzej Franaszek, Ryszard Krynicki, Marian Stala i Piotr Śliwiński," Tygodnik Powszechny 2008, no. 44, appendix on Herbert, p. 406. 
"Elegy for the Departure of Pen Ink and Lamp." ${ }^{41}$ Yet these examples do not exhaust the list of poems that have spawned critical microhistories. Thus we ought to extend the list by "To Marcus Aurelius," "Stool," "Wawel," "Nike Who Hesitates," "Forest of Arden," "Arion," "Baptism," "At the Gate of the Valley," "A Tale," "Balconies," "Furnished Room," "Drum Song," "Substance," "Apollo and Marsyas," "The Return of the Proconsul," "Study of the Object," "Pebble," "Why the Classics," "Prologue," "Mr. Cogito Reflects on Suffering," "The History of the Minotaur," Mr. Cogito Tells of the Temptation of Spinoza," "Mr. Cogito Seeks Advice," "Mr. Cogito on Upright Attitudes," "From the Top of the Stairs," "Photograph," "Old Masters," "Prayer of the Traveler Mr. Cogito," "To Ryszard Krynicki - A Letter," "Mr. Cogito’s Monster," "Pan Cogito - Notes from the House of the Dead," "Report from a Besieged City," "Oaks," "A Small Heart," "Black Figurine by Eksekias," "Rovigo," the cycle of "Breviaries," "Mr Cogito. The Soul's Current Position," "Tenderness," and "Fabric." It is believed that the best way forward vis a vis the elicitation of hitherto unknown aspects of Herbert's creative silhouette consists in renewed detailed re-examination of his works. Thus, it stands to reason that the overall inventory of interpretations is steadily accruing, with critics going over poems' each and every line with a finetooth comb. And the odds are that even those purportedly second-tier poetic works, when subjected to renewed scrutiny, stimulate researchers to the point of encouraging separate studies and analytical monographs.

In lockstep with the developments presented above, we are witnessing an expanding presence of collections compiling interpretations illustrating a vast array of styles, subjects, or philosophical messages. ${ }^{42}$ Conversely, one particular poem may reappear in many different contexts, functioning as a synecdoche for the entire entity. All this goes to show that we are busy seeking out and addressing extant interpretative blind spots. One of the implications of the process could be a reshuffling within the cannon of Herbert's poems along the lines of the criteria of perceived artistry or relevance of the messages. At the risk of sounding platitudinous, we must reiterate that complete and definitive interpretations can exist only as a projection of ideal entities. Yet in practice, the

${ }^{41}$ For example: J. Łukasiewicz, "Elegia na odejście pióra atramentu lampy” [in:] idem, Poezja Zbigniewa Herberta, op. cit.; W. Ligęza, "Elegie Zbigniewa Herberta” [in:] Twórczość Zbigniewa Herberta..., op. cit.; A. Legeżyńska, "Gest pożegnania," D. Pawelec, "Elegia" [these two texts] [in:] Niepewna jasność tekstu..., op. cit.; W. Kudyba, "Ostatnie rzeczy Herberta. Troska w 'Elegii na odejście pióra atramentu lampy”" [in:] Gąszcz srebrnych liści. Interpretacje wierszy Zbigniewa Herberta, ed. J.M. Ruszar, Kraków 2015, pp. 171-182.

${ }^{42}$ See also: Dlaczego Herbert. Wiersze $i$ interpretacje, ed. M. Woźniak-Łabieniec, J. Wiśniewski, Łódź 1992; J. Łukasiewicz, Poezja Zbigniewa Herberta, op. cit.; D. Opacka-Walasek, Czytając Herberta, op. cit.; Niepewna jasność tekstu..., op. cit. [part 1]; Gąszcz srebrnych liści..., op. cit.; Zemsta ręki śmiertelnej. Interpretacje wierszy poetów XX wieku, ed. J.M. Ruszar, D. Siwor, Kraków 2017 [the first sequence of texts is dedicated to Herbert's poems]. 
process of discovery in terms of interpretation will be an inexhaustible source of fodder for literary theory experts.

Scholarly poetry - poesia docta - invites comparison, encourages reconstruction of multi-layered allusions to literature, fine arts, philosophy, and diverse branches of science. As regards literary-theory narratives concerning Herbert's poetry, they are often anchored in erudite commentary. Thus, interpretative decryption aspires to reach as far back as the point of inspiration, and such a process rests on an investigative search for the origins of a poem, or even, if one may say so, a reversion to the pretextual stage of the poet's pursuits. Of course, it would be wrong to surmise that everything boils down only to recognizing allusions, to parsing out seamlessly patchworked poetic collage, or identifying quotations or quasi-quotations. Rather, we have to address the fundamental questions of how Herbert's inventory of topoi blazes a new trail in terms of poetic novelty, and we ought to gauge the calibre of his originality in harnessing cultural tropes.

Such an approach exhibits consanguinity with Herbert-related comparative studies. There are valid arguments why the artistic legacy of the author of Still Life with a Bridle lends itself to comparison with the greats and even with the consummate paragons of 19th- and 20th-century literature. Firstly, Herbert's literary sensibilities centre on the ground zero of the ideas of his time; secondly, the values he champions evince profound universal provenance; and thirdly, his works proffer models for confronting the challenges of the world, both in its modern and post-modern guises. That is why researchers set out to establish analogies between Herbert's poetic pronouncements with those found in Joseph Conrad, Friedrich Hölderlin, Rainer Maria Rilke, T.S. Eliot, ${ }^{43}$ Constantine P. Cavafy, W.H. Auden, Sylvia Plath, Paul Celan, Joseph Brodsky, Seamus Heaney, Cyprian Kamil Norwid, Jerzy Liebert, Polish WWII-generation poets (Tadeusz Gajcy, Krzysztof Kamil Baczyński, Zdzisław Stroiński, Tadeusz Borowski), Tadeusz Różewicz, Witold Wirpsza, Wisława Szymborska, Stanisław Grochowiak, Jarosław Marek Rymkiewicz, Miron Białoszewski, Stanisław Barańczak, and Adam Zagajewski. As far as Herbert's essay-writing is concerned, the list of resemblances features references to such names as Józef Wittlin, Gustaw Herling-Grudziński, Józef Czapski, Konstanty Jeleński, and Andrzej Kijowski. As regards studies featuring parallels and dialogues with and biographical correspondences between Herbert and Czesław Miłosz, they should be treated as a category in its own right. ${ }^{44}$ Another significant critical

${ }_{43}$ Rilke and Eliot, mentioned in the much-cited poem "To Ryszard Krynicki - A Letter" (from the collection Report from a Besieged City) are of special significance to Eliot. See also: K. Kuczyńska-Koschany, Rilke poetów polskich, Toruń 2017, p. 278 and fol. (2 ${ }^{\text {nd }}$ ed.). Also: P. Łuszczykiewicz, "Rilke, Eliot, Herbert...," Dialog 1998, no. 12, pp. 143-144.

44 See A. Fiut, "Ukryty dialog" [in:] idem, W stronę Mitosza, Kraków 2003, pp. 225-247, reprint [in:] Niepewna jasność tekstu..., op. cit., pp. 171-190; A. Fiut, "Męczeństwo i ziemskie rozkosze. O poetyckiej galerii Miłosza i Herberta" [in:] Zmyst wzroku, zmyst sztuki. Prywatna 
segment of a comparative nature concerns the polemic dialogue of the poet with Henryk Enzelberg, his philosophical mentor.

However, when all is said and done, any attempt at clear-cut categorisation ineluctably brings in the hazard of oversimplification and omission. In the case of this study, the prioritisation of the focus on wide-ranging presentation to some extent has been at the expense of evaluation, which ends up being eclipsed or even marginalised. Furthermore, embarking on the task of describing diverse ways of critical reception does not put one in an enviable position, as opining about ways of assimilating Herbert's legacy belongs to the very same long lineage of judgements and sentiments. Hence, one ought to take such an analysis to the next level - that of meta-reflection, where the mind reflects on the "reception of reception." Apart from showcasing impressive research practices geared to synthetic consolidation and organisation, the publications presented in this study nonetheless display shortcomings, such as failure to maintain enough notional discipline, resulting in blurred focus, repetitions, trivialisation of perspective, a skein of redundant comments, and derivative, marginal opinions.

Jumping on the critical bandwagon is not conducive to attentive reading, as perpetuating the same perspective in successive studies may take the toll of gradual erosion of novelty. That state of affairs is the unintended consequence of standardisation in academe and pursuits for fashionable methods and languages of interpretation. Moreover, the history of the reception of literary works is punctuated with the unearthing of novelties and subsequently abandoning them, all due to the competitive one-upmanship prevailing in the field of criticism. ${ }^{45} \mathrm{I}$ do not subscribe to the prognostic pronouncement that "the moment of mature reception of Herbert's legacy is still ahead of us." ${ }^{46} \mathrm{I}$ be-

historia sztuki Zbigniewa Herberta, part 2, Lublin 2006, pp. 11-29; B. Carpenter, "Czesław Miłosz i Zbigniew Herbert - poeta wygnania” [in:] Literatura polska na obczyźnie, ed. J. Bujnowski, London 1985, pp. 176-192; D. Opacka-Walasek, '...pozostać wiernym niepewnej jasności.' Wybrane problemy poezji Zbigniewa Herberta, Katowice 1996, pp. 54-59, 68-72; J. Tomkowski, "Herbert contra Miłosz" [in:] idem, Dwadzieścia lat z literatura 1977-1996, Warszawa 1998;

A. Biskupski, "Miłosz - Herbert. Poznanie dobra i zła" [in:] Herbert i znaki czasu..., op. cit.; S. Stabro, "Poetycka idea narodu w 'Substancji' Zbigniewa Herberta i w 'Narodzie' Czesława Miłosza” [in:] Portret z początku wieku. Twórczośc Zbigniewa Herberta - kontynuacje i rewizje, ed. W. Ligęza in collab. with M. Cicha, Lublin 2005; Z. Zarębianka, "Spór o wartości? Herbert Miłosz" [in:] Dialog i spór. Zbigniew Herbert a inni poeci i eseiści, ed. J.M. Ruszar, D. Koman, Lublin 2006, pp. 108-117, reprint [in:] Z. Zarębianka, Wtajemniczenia (w) Mitosza, Kraków 2014, pp. 59-70; D. Zawistowska-Toczek, “'Pojedynek wieszczów.’ Konflikt z Czesławem Miłoszem" [in:] D. Zawistowska-Toczek, Stary poeta..., op. cit., pp. 175-202, more recently: R. Sioma, “'Źródło nieba na ziemi.' Metafizyka zachwytu: Miłosz - Herbert (rekonesans)” [in:] Zemsta ręki śmiertelnej..., op. cit., pp. 99-112.

45 The issue is addressed in more detail in my text: "Sukces, przesyt, znaki obecności" [in:] Herbert, a suppl. to Kwartalnik Artystyczny 2008, no. 2, pp. 40-45.

${ }^{46}$ A. Grabowski, J. Kopciński, "Herbert na językach - wyznanie wstępne" [in:] Herbert na jezzykach..., op. cit., p. 8. 
lieve we should know better than to multiply subsequent exegeses and, instead, attentively revisit the existing library of texts on Herbert's output, always remembering to give priority to classic interpretations, forming an established cannon.

To date, the creator of Mr. Cogito has been dubbed a poet of culture, an authority on painting, an artist of conscientious objection who condemns the evils of communism, a writer cultivating historiosophical, metaphysical, and existential thinking, as well as a radical, "who invariably, in all circumstances, swore by his allegiance to his national, political, artistic, and philosophical ideals." ${ }^{77}$ Zbigniew Herbert has been a moralist, standing up for the precious inalienable rights of the underdog; an ironist, dwelling on tampered weights and measurements we willingly resort to when in fear or when seduced by conformity. In addition, Herbert has been perceived as a poet of suffering, and someone probing into the process of passing away and death.

At the same time, we ought not to lose sight of the caution given by Adam Zagajewski, in which we can also discern overtones of an assurance of the inexhaustible potential for refreshed reception:

Even otherwise outstanding publications, books or monographs, have endeavoured to pinpoint the overarching principle of Hebert's poetry: neoclassicism, a refugee from utopia, a poet of loyalty, a voice of the suffering. But his writing is puzzlingly impenetrable to critical exploration; and undeniably it defiantly resists any ambition to pinpoint its unique, central core..$^{48}$

We can hazard a guess that boredom is the last thing that future researchers of Herbert's oeuvre will struggle with, as, despite the innumerable attempts at elucidation, some ideas still await discovery, while others deserve a thorough "reread." This writer with a taste for antinomy and paradox will never cease to encourage his readers to return time and again to his work.

Translated by Przemystaw Michalski

\section{Bibliography}

Adamiec M., '...Pomnik troche niezupetny...'Rzecz o apokryfach w poezji Zbigniewa Herberta, Gdańsk 1996.

Adamowska J., Różewicz i Herbert. Aksjologiczne aspekty twórczości, Kraków 2012.

${ }^{47}$ G. Herling-Grudziński, "Był wierny” [in:] Wierność..., op. cit., p. 252.

48 A. Zagajewski, "Początek wspominania" [in:] Wierność..., op. cit., pp. 296-297, first printed: Zeszyty Literackie 1999, no. 4. 
Antoniuk M., Otwieranie gtosu. Studium o wczesnej twórczości Zbigniewa Herberta (do 1957 roku), Kraków 2009.

Archiwum Zbigniewa Herberta. Inwentarz, ed. H. Citko, Warszawa 2008.

Balcerzan E., "Arkadyjczyk w oblężonym mieście (O poezji Zbigniewa Herberta)," Twórczość 1986, no. 10.

Barańczak S., Uciekinier z Utopii. O poezji Zbigniewa Herberta, London 1984.

Bobryk R., Koncept poezji i poety w wierszach Zbigniewa Herberta, Siedlce 2017.

Bór nici. Wątki klasyczne $i$ romantyczne $w$ twórczości Zbigniewa Herberta, ed. M. Mikołajczak, Kraków 2011.

Carpenter B., "Czesław Miłosz i Zbigniew Herbert - poeta wygnania" [in:] Literatura polska na obczyźnie, ed. J. Bujnowski, London 1985.

Czutość dla Minotaura. Metafizyka i mitość konkretu, ed. J.M. Ruszar, M. Cicha, Lublin 2005.

Czytanie Herberta, ed. P. Czapliński, P. Śliwiński, Poznań 1995.

Dąbrowski S., "Hamlet i Fortynbras (Między literaturą a rzeczywistościa)," Tygodnik Powszechny 1971, no. 8.

Dialog i spór. Zbigniew Herbert a inni poeci i eseiści, ed. J.M. Ruszar, D. Koman, Lublin 2006.

Dlaczego Herbert. Wiersze i interpretacje, ed. M. Woźniak-Łabieniec, J. Wiśniewski, Łódź 2004.

Dudek J., Granice wyobraźni, granice stowa. Studia z literatury porównawczej XX wieku, Kraków 2008.

Dzień M., Motywy eschatologiczne w poezji Zbigniewa Herberta. Studium analityczno-interpretacyjne, vols. 1-2, Bielsko Biała 2014.

Fiut A., "Język wiary i niewiary” [in:] idem, Pytanie o tożsamość, Kraków 1995.

Fiut A., "Ukryty dialog" [in:] idem, W stronę Mitosza, Kraków 2003.

Franaszek A., Ciemne źródto (o twórczości Zbigniewa Herberta), London 1998.

Gaszcz srebrnych liści. Interpretacje wierszy Zbigniewa Herberta, ed. J.M. Ruszar, Kraków 2015.

Grabowski A., Herbert-Hermes. Konteksty nowoczesności w esejach, dramatach i wierszach Zbigniewa Herberta, Kraków 2013.

Herbert i znaki czasu. Colloquia Herbertiana, ed. E. Feliksiak, M. Leś, E. Sidoruk, vol. 1: Białystok 2001, vol. 2: Białystok 2002.

Herbert na jezzykach. Wspótczesna recepcja twórczości Zbigniewa Herberta $w$ Polsce i na świecie, ed. A. Grabowski, J. Kopciński, J. Snopek, Warszawa 2010.

Herbert nieoswojony, ed. W. Browarny, J. Orska, A. Poprawa, Wrocław 2008.

Herbert nieznany. Rozmowy, oprac. H. Citko, Warszawa 2008.

Herbert. Poetyka, wartości i konteksty, ed. E. Czaplejewicz, W. Sadowski, Warszawa 2002.

Herbert Środkowoeuropejczyk. Twórczośc Zbigniewa Herberta w kontekstach i kontaktach środkowoeuropejskich, ed. K. Krasuski, Katowice 2011.

Herbert Z., Gtosy Herberta, ed. B. Toruńczyk, Warszawa 2008.

Herbert Z., Labirynt nad morzem, Warszawa 2000. 
Herbert Z., 'Mistrz z Delft' $i$ inne utwory odnalezione, ed. B. Toruńczyk, collab. H. Citko, Warszawa 2008.

Herbert Z., Węzet gordyjski oraz inne pisma rozproszone 1948-1998, ed. P. Kądziela, Warszawa 2001.

Herbert Z., Wiersze zebrane, ed. R. Krynicki, Kraków 2008.

Herbert Z., Barańczak S., Korespondencja, ed. B. Toruńczyk, Warszawa 2005.

Hryniewicz K. Cogito i dubito. Dyskurs estetyczny w poezji Zbigniewa Herberta i Tadeusza Różewicza, Kraków 2014.

Kaliszewski A., Nostalgia stylu. Neoklasycyzm liryki polskiej XX wieku w krytyce, badaniach i poetykach immanentnych (w kontekśsie tradycji poetologicznej klasycyzmu), Kraków 2007.

Kamieńska A., "Niewierny Tomasz i świat," Twórczość 1957, no. 10-11.

Kamieńska A., "Okrucieństwo mitu” [in:] eadem, Od Leśmiana. Najpiękniejsze wiersze polskie, Warszawa 1974.

Kądziela P., Twórczość Zbigniewa Herberta. Monografia bibliograficzna, vols. 1-2, Warszawa 2009.

Kluba A., "Zbigniew Herbert" [in:] eadem, Poemat proza w Polsce, WarszawaToruń 2014.

Kłosiński K., "Poezja zaimków. O 'Przesłaniu Pana Cogito’ Zbigniewa Herberta” [in:] Liryka polska XX wieku. Analizy i interpretacje. Seria trzecia, ed. W. Wójcik, J. Kisielowa, Katowice 2005.

Kornhauser J., Uśmiech Sfinksa, Kraków 2001.

Kowalczyk A., “Złote runo nicości. 'Przesłanie Pana Cogito’ - próba lektury,” Tygodnik Powszechny 1983, no. 11.

Kramkowska-Dąbrowska A. Gabinet luster. Śmiech w twórczości Zbigniewa Herberta, Warszawa 2015.

Kuczyńska-Koschany K., Rilke poetów polskich, Toruń 2017.

Kwiatkowski J., "Klerk mężny," Życie Literackie 1957, no. 40.

Ligęza W., Bez rutyny. O poezji Wistawy Szymborskiej i Zbigniewa Herberta, Kraków 2016.

Liryka i fenomenologia. Zbigniew Herbert i Tadeusz Różewicz w kręgu myśli Ingardenowskiej, ed. J.M. Ruszar, D. Siwor, Kraków 2016.

Łukasiewicz J., Herbert, Wrocław 2001.

Łukasiewicz J., Poezja Zbigniewa Herberta, Warszawa 1995.

Łuszczykiewicz P., "Rilke, Eliot, Herbert...," Dialog 1998, no. 12.

Matuszewski R., "Wiersze piękne i rozumne" [in:] idem, Doświadczenia i mity, Warszawa 1964.

Mazurkiewicz-Szczyszek A., W asyście jakich dzwonów. Obrazy miasta w twórczości Zbigniewa Herberta, Lublin 2008.

Michnik A., "Potęga smaku" [in:] idem, $Z$ dziejów honoru w Polsce. Wypisy więzienne, Paris 1985.

Między nami a świattem. Bóg i świat w twórczości Zbigniewa Herberta, ed. G. Halkiewicz-Sojak, J.M. Ruszar, R. Sioma, Toruń-Kraków 2012. 
Mikołajczak M., Pomiędzy końcem i apokalipsą. O wyobraźni poetyckiej Zbigniewa Herberta, Wrocław 2007.

Mikołajczak M., Światy z marzenia. Echa romantyczne w poezji Zbigniewa Herberta, Zielona Góra-Kraków 2013.

Mikołajczak M., W cieniu heksametru. Interpretacje wierszy Zbigniewa Herberta, Zielona Góra 2004.

Nagta wyspa. Studia i szkice o pisarstwie Zbigniewa Herberta, ed. P. Próchniak, Lublin 2015.

Nasiłowska A., "Zbigniew Herbert: Pan Cogito ma kłopoty” [in:] Sporne postaci polskiej literatury wspótczesnej. Kontynuacje, ed. A. Brodzka, L. Burska, Warszawa 1996.

Nawarecki A., "Trzy ostatnie słowa Pana Cogito. O wierszu Zbigniewa Herberta 'Przesłanie Pana Cogito'" [in:] Kanonada. Interpretacje wierszy polskich (19391989), ed. A. Nawarecki, D. Pawelec, Katowice 1999.

Niepewna jasność tekstu. Szkice o twórczości Zbigniewa Herberta 1998-2008, ed. J.M. Ruszar, Kraków 2009.

Opacka-Walasek D., Czytajac Herberta, Katowice 2001.

Opacka-Walasek D., '...pozostać wiernym niepewnej jasności.' Wybrane problemy poezji Zbigniewa Herberta, Katowice 1996.

Panas P., "Herbertowe 'ars moriendi"” [in:] Wyraz wytuskany z piersi. Szkice o twórczości Zbigniewa Herberta, ed. B. Gautier, D. Knysz-Tomaszewska, J.M. Ruszar, M. Zieliński, Lublin 2006.

Pietrych K., "Spotkanie drugie: Zbigniew Herbert" [in:] eadem, Co poezji po bólu. Empatyczne przestrzenie lektury, Łódź 2009.

Pojęcia kietkujące z rzeczy. Filozoficzne inspiracje twórczości Zbigniewa Herberta, ed. J.M. Ruszar, Kraków 2010.

Portret z początku wieku. Twórczość Zbigniewa Herberta - kontynuacje i rewizje, ed. W. Ligęza with collab. of M. Cichej, Lublin 2005.

Poznawanie Herberta, sellect. and foreword A. Franaszek, Kraków 1998.

Poznawanie Herberta 2, ed. A. Franaszek, Kraków 2000.

Pracownia Herberta. Studia nad procesem tekstotwórczym, ed. M. Antoniuk, Kraków 2017.

Ruszar J.M., Stońce republiki. Cywilizacja rzymska w twórczości Zbigniewa Herberta, Kraków 2014.

Ruszar J.M., Stróż brata swego. Zasada odpowiedzialności w liryce Zbigniewa Herberta, Lublin 2004.

Ruszar J.M., Wytarty profil rzymskich monet. Ekonomia jako temat literacki w twórczości Zbigniewa Herberta, Kraków 2016.

Siemaszko P., Wehikut pasji i cnoty. Myśl o pięknie w twórczości Zbigniewa Herberta, Bydgoszcz 2016.

Sioma R., Krzesto i zmięta serweta. Szkice o twórczości Zbigniewa Herberta, Kraków 2017.

Śniedziewska M., Wierność rzeczywistości. Zbigniew Herbert o postawie wobec świata i problemach jego reprezentacji, Kraków 2013. 
Tomkowski J., "Herbert contra Miłosz" [in:] idem, Dwadzieścia lat z literatura 1977-1996, Warszawa 1998.

Toruńczyk B., „Dukt pisma, dukt pamięci,” Zeszyty Literackie 1999, no. 4.

Trznadel J., „Kamieniowanie mądrości” [in:] idem, Ptomień obdarzony rozumem. Poezja w poezji i proza poezja. Eseje, Warszawa 1978.

Twórczość Zbigniewa Herberta, ed. M. Woźniak-Łabieniec, J. Wiśniewski, Kraków 2001.

Upór i trwanie. Wspomnienia o Zbigniewie Herbercie, ed. K. Szczypka, Wrocław 2000.

Urbankowski B., Poeta, czyli cztowiek zwielokrotniony. Szkice o Zbigniewie Herbercie, Radom 2004.

Wierność. Wspomnienia o Zbigniewie Herbercie, sellect. and ed. A. Romaniuk, Warszawa 2014.

Wyka K., "Składniki świetlnej struny," Żcie Literackie 1956, no. 42.

Wyka K., "Tren Fortynbrasa” [in:] idem, Rzecz wyobraźni, Warszawa 1977.

Wyka M., Niecierpliwość krytyki. Recenzje i szkice z lat 1961-2005, Kraków 2006.

Zagajewski A., "Wiersze Herberta, które lubię najbardziej” [in:] idem, Poezja dla początkujących, Warszawa 2017

Zawistowska-Toczek D., Stary poeta. 'Ars moriendi' w póżnej twórczości Zbigniewa Herberta, Lublin 2008.

Zemsta ręki śmiertelnej. Interpretacje wierszy poetów XX wieku, ed. J.M. Ruszar, D. Siwor, Kraków 2017.

Zimand R., Ogród i barbarzyńca [in:] idem, Czas normalizacji. Szkice czwarte, London 1989.

“'Złote runo nicości.' O 'Przesłaniu Pana Cogito’ (...) discussion by Stefan Chwin, Tadeusz Dąbrowski, Andrzej Franaszek, Ryszard Krynicki, Marian Stala i Piotr Śliwiński," Tygodnik Powszechny 2008, no. 44, supplement Herbert.

Zmyst wzroku, zmyst sztuki. Prywatna historia sztuki Zbigniewa Herberta, part. 2, ed. J.M. Ruszar, Lublin 2006. 